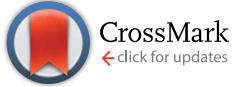

Cite this: RSC Adv., 2017, 7, 12953

Received 27th December 2016 Accepted 16th February 2017

DOI: 10.1039/c6ra28760c

rsc.li/rsc-advances

\section{Investigation of antioxidant and detoxifying capacities of some date cultivars (Phoenix dactylifera L.) irrigated with sewage water}

\author{
Wesam H. Abdulaal, ${ }^{a}$ Mustafa Zeyadi, ${ }^{a}$ Othman A. S. Baothman, ${ }^{a}$ Mazin A. Zamzami, \\ Hani Choudhry, ${ }^{a}$ Yaaser Q. Almulaiky, ${ }^{a}$ Rashad M. Saleh ${ }^{a}$ and Saleh A. Mohamed ${ }^{\star a b}$
}

\section{Introduction}

Sewage and industrial wastewater is commonly used for irrigating agricultural fields in developing countries. ${ }^{1,2}$ Continuous use of wastewater leads to the enrichment of soil with essential macro and micronutrients. ${ }^{3,4}$ Micro-nutrients are beneficial for the growth and metabolism of the plants at lower concentrations, but become toxic when in excess of the requirement. Several micronutrients are heavy metals and are known to produce undesirable effects in plants at higher concentrations. ${ }^{5}$ It has been shown that there is an increase in reactive oxygen species (ROS) production in plants due to pathogen attacks, wounding, herbivore feeding, UV light, heavy metals and others. ${ }^{6,7}$ ROS can damage DNA, proteins, lipids and chlorophyll. ${ }^{8}$ Plant damage occurs when the capacity of antioxidant processes and detoxification mechanisms are lower than the amount of ROS production. ${ }^{9}$ Plants have developed complex systems protecting them from ROS, consisting of several enzymes and antioxidants. Those mechanisms can slow down or even stop the oxidation of biomolecules and block the process of oxidative chain reactions. ${ }^{10}$ Increase in the amount of phenolic compounds can be observed under different environmental factors and stress conditions. ${ }^{6,11}$ The induction of phenolic compound biosynthesis was observed in wheat in response to nickel toxicity ${ }^{6}$ and in maize in response to aluminum. ${ }^{12}$ Phenolics have various functions in plants.

${ }^{a}$ Biochemistry Department, Faculty of Science, King Abdulaziz University, Jeddah, Kingdom of Saudi Arabia. E-mail: saleh38@hotmail.com; Tel: +966543395119 ${ }^{b}$ Molecular Biology Department, National Research Center, Dokki, Cairo, Egypt
Antioxidant action of phenolic compounds occurs due to their high tendency to chelate metals. Phenolics possess hydroxyl and carboxyl groups, which are able to bind particularly iron and copper. ${ }^{13}$

In addition to phenolic and flavonoid antioxidant compounds, plants also possess several important enzymes, including superoxide dismutase, peroxidase, and catalase. ${ }^{14}$ Peroxidases play a significant role in the defense against oxidative stress and have been suggested to be indicators of metal toxicity. ${ }^{15}$ Additionally, polyphenoloxidase plays an important role in the control of oxidative processes increased under stressful conditions. ${ }^{16,17}$ The enzymes glutathione- $S$-transferases have been associated with the detoxification of xenobiotics, limiting oxidative damage and other stress responses in plants. ${ }^{18,19}$ In general, plants with higher glutathione-S-transferase levels are more tolerant to herbicide exposure. They can be induced by various environmental stimuli including $\mathrm{H}_{2} \mathrm{O}_{2}$ and metals. ${ }^{20,21}$

Date palm (Phoenix dactylifera L.) is one of the most commonly consumed fruit in the Saudi Arabia..22,23 The production of dates of several excellent commercial cultivars reached about one million ton in 2010 season. ${ }^{23}$ It is one of the main sources of naturally dietary antioxidants such as phenolic compounds that critically required for keeping human health. ${ }^{22,24}$ Date palm trees are usually irrigated by the flood irrigation system that uses an abundant amount of water. ${ }^{25}$ Due to the agriculture in the Saudi Arabia faces many challenges, typical for a semi-arid to hyper-arid climate, included scarce water resources, low annual rainfall, extremely high temperatures, and enormous evapo-transpiration. Some farmers irrigated the date palm with sewage water. We hypothesize that the 
date palm tree obstructs the toxicity accompanied with sewage by its antioxidant and detoxification mechanisms. Therefore, the present study was conducted to compare the effect of irrigation by municipal water (MW) and sewage water (SW) on the total phenolic and flavonoid contents, and antioxidant activities of some commercially Saudi date palm cultivars. The antioxidant, oxidant and detoxifying enzymes were also evaluated.

\section{Experimental}

\section{Plant material}

Samples of fresh date fruits from three cultivars, Agwa, Anbr and Safawi, irrigated by using MW and SW, were harvested at Tamer stage from Al-Madinah Al-Munawwarah, Saudi Arabia.

\section{Preparation of methanol extract}

Two $\mathrm{g}$ of dried date fruits were extracted by shaking at $150 \mathrm{rpm}$ for $24 \mathrm{~h}$ with $20 \mathrm{~mL}$ methanol (80\%) and filtered through filter paper no. 1. The filtrate was designated as methanol extract. The experiment was repeated 3 times for each sample.

\section{Estimation of phenolic content}

Total phenolic content was measured according to Velioglu et $a l .{ }^{26}$ Fifty $\mu \mathrm{L}$ of the methanol extract was mixed with $100 \mu \mathrm{L}$ Folin-Ciocalteu reagent and $850 \mu \mathrm{L}$ of methanol and allowed to stand for $5 \mathrm{~min}$ at ambient temperature. A $500 \mu \mathrm{L}$ of $20 \%$ sodium carbonate was added and allowed to react for $30 \mathrm{~min}$. Absorbance was measured at $750 \mathrm{~nm}$. Total phenolic content was quantified from a calibration curve obtained by measuring the absorbance of known concentrations of gallic acid. The results are expressed as $\mathrm{mg}$ gallic acid equivalent (GAE)/100 $\mathrm{g}$ tissues.

\section{Estimation of flavonoid content}

Total flavonoid content was determined using a modified colorimetric method described by Zhishen et $a .^{27}$ The catechin was used as a standard. Methanol extract or standard solution $(250 \mu \mathrm{L})$ was mixed with distilled water $(1.25 \mathrm{~mL})$ and $5 \%$ $\mathrm{NaNO}_{2}$ solution $(75 \mu \mathrm{L})$. After standing for $6 \mathrm{~min}$, the mixture was combined with $10 \% \mathrm{AlCl}_{3}$ solution $(150 \mu \mathrm{L})$. One $\mathrm{M} \mathrm{NaOH}$ $(0.5 \mathrm{~mL})$ and distilled water $(275 \mu \mathrm{L})$ was added to the mixture $5 \mathrm{~min}$ later. The absorbance of the solutions at $510 \mathrm{~nm}$ was then measured. Total flavonoid content was quantified from a calibration curve obtained by measuring the absorbance of known concentrations of catechin. The results were expressed as mg catechin equivalent (CE)/100 g tissues.

\section{Heavy metal determination}

One $g$ date fruit was incinerated in a porcelain crucible at $600{ }^{\circ} \mathrm{C}$ for $16 \mathrm{~h}$. Ten $\mathrm{mL}$ of deionized water was added and filtered by filter paper Whatman no. 1. The filtrate was then analyzed for levels of heavy metals using inductively coupled plasma atomic emission spectrometry (ICPE-9000; Shimadzu Scientific Instruments). The obtained results were recorded as $\mathrm{mg} \mathrm{kg}^{-1} \mathrm{DW}$.

\section{Evaluation of antioxidant activity}

DPPH radical scavenging assay. Free radical scavenging activity of methanol extract was determined using the 1,1diphenyl-2-picrylhydrazyl (DPPH) method. ${ }^{28}$ A methanol extract $(0.1 \mathrm{~mL})$ was added to $0.9 \mathrm{~mL}$ of freshly prepared DPPH methanol solution $(0.1 \mathrm{mM})$. An equal amount of methanol was used as a control. After incubation for $30 \mathrm{~min}$ at room temperature in the dark, the optical density (OD) was measured at $517 \mathrm{~nm}$ using a spectrophotometer. Activity of scavenging (\%) was calculated using the following formula: DPPH radical scavenging $\%=[(\mathrm{OD}$ control - OD sample)/OD control] $\times 100$. IC $_{50}$ value was the inhibition concentration as $\mu \mathrm{g}$ phenolic concentration of the test sample that decreases $50 \%$ of initial radical. $\mathrm{The} \mathrm{IC}_{50}$ values were calculated from the dose responses curves.

ABTS radical cation decolorization assay. ABTS (2,2' -azinobis (3-ethylbenzo-thiazoline-6-sulfonic acid) also forms a relatively stable free radical, which decolorizes in its non-radical form. The spectrophotometric analysis of $\mathrm{ABTS}^{*+}$ scavenging activity was determined according to the method of Re et al. ${ }^{29}$ ABTS $^{+}$was produced by reacting $7 \mathrm{mM}$ ABTS in $\mathrm{H}_{2} \mathrm{O}$ with $2.45 \mathrm{mM}$ potassium persulfate $\left(\mathrm{K}_{2} \mathrm{~S}_{2} \mathrm{O}_{8}\right)$, stored in the dark at room temperature for $16 \mathrm{~h}$. The $\mathrm{ABTS}^{{ }^{++}}$solution was diluted to give an absorbance of $0.750 \pm 0.025$ at $734 \mathrm{~nm}$ in $0.1 \mathrm{M}$ sodium phosphate buffer (pH 7.4). Then, $1 \mathrm{~mL}$ of $\mathrm{ABTS}^{\cdot+}$ solution was added to methanol extract. The absorbance was recorded $1 \mathrm{~min}$ after mixing and the percentage of radical scavenging was calculated relative to a blank containing no scavenger. The extent of decolorization was calculated as percentage reduction of absorbance. The scavenging capability of test compounds was calculated using the following equation: $\mathrm{ABTS}^{{ }^{++}}$scavenging $(\%)=[(\mathrm{OD}$ control - OD sample $) / \mathrm{OD}$ control $] \times 100 . \mathrm{IC}_{50}$ value is the inhibition concentration as $\mu \mathrm{g}$ phenolic concentration of the test sample that decreases $50 \%$ of initial radical. The $\mathrm{IC}_{50}$ values were calculated from the dose response curves.

Phosphomolybdenum complex assay. Spectrophotometric evaluation of antioxidant activity by the formation of a phosphomolybdenum complex was carried out according to Prieto et al. $^{30}$ Methanol extract was mixed with $1 \mathrm{~mL}$ of reagent solution (0.6 M sulfuric acid, $28 \mathrm{mM}$ sodium phosphate and $4 \mathrm{mM}$ ammonium molybdate). The tubes were capped and incubated in a thermal block at $95{ }^{\circ} \mathrm{C}$ for $90 \mathrm{~min}$. The samples were cooled to room temperature, and the absorbance of aqueous solutions of each sample was measured at $695 \mathrm{~nm}$ against a blank. The antioxidant activity was expressed as the absorbance of the sample. $\mathrm{EC}_{50}$ value ( $\mu \mathrm{g}$ phenolic concentration) is the effective concentration at which the absorbance was 0.5 for the formation of phosphomolybdenum complex.

\section{Enzymes measurements}

Crude enzyme extract. One $\mathrm{g}$ of fresh date was homogenized with $20 \mathrm{mM}$ Tris-HCl buffer, pH 7.2 using homogenizer. The homogenate was centrifuged at $13500 \times g$ for $10 \mathrm{~min}$ at $4{ }^{\circ} \mathrm{C}$. The supernatant was designed as crude extract and stored at $-20{ }^{\circ} \mathrm{C}$ for further analysis.

Peroxidase assay. Peroxidase activity was carried out according to Miranda et al. ${ }^{31}$ The reaction mixture containing in 
one mL: $8 \mathrm{mM} \mathrm{H}_{2} \mathrm{O}_{2}$, $40 \mathrm{mM}$ guaiacol, $50 \mathrm{mM}$ sodium acetate buffer, pH 5.5 and $0.1 \mathrm{~mL}$ crude extract. The change in absorbance at $470 \mathrm{~nm}$ due to guaiacol oxidation was followed for 1 min using a spectrophotometer. One unit of peroxidase activity was defined as the amount of enzyme which increases the O.D. 1.0 per min under standard assay conditions.

Polyphenoloxidase assay. Polyphenoloxidase activity was assayed with catechol as a substrate according to the spectrophotometric procedure of Jiang et $a l^{32}$ The crude extract (0.2 $\mathrm{mL}$ ) was rapidly added to $2.8 \mathrm{~mL}$ of $20 \mathrm{mM}$ catechol solution prepared in $0.01 \mathrm{M}$ sodium phosphate buffer, $\mathrm{pH}$ 6.8. The increase in absorbance at $400 \mathrm{~nm}$ and $25{ }^{\circ} \mathrm{C}$ is recorded for 3 min using a spectrophotometer. One unit of enzyme activity is defined as the amount of the enzyme that causes a change of 0.1 in absorbance per min under standard assay conditions.

Glutathione- $\boldsymbol{S}$-transferase assay. The glutathione- $S$-transferase activity was determined spectrophotometrically with the aromatic substrate 1-choloro-2,4-dinitrobenzen (CDNB) by monitoring the change in absorbance, due to thioether formation, at $340 \mathrm{~nm}$ and $25{ }^{\circ} \mathrm{C}$ as described by Habig et al. ${ }^{33}$ Unless otherwise stated, the assay mixture contained in a total volume of $1 \mathrm{~mL}, 0.1 \mathrm{M}$ potassium phosphate buffer, $\mathrm{pH} 6.5,1 \mathrm{mM}$ CDNB in ethanol (final concentration of ethanol less than $4 \%$ ), $1 \mathrm{mM}$ glutathione reduced form (GRH), and the enzyme solution. The increase in absorbance at $340 \mathrm{~nm}$ of the complete assay reaction mixture was monitored against a control containing buffer instead of the enzyme and treated similarly. The extinction coefficient of product is taken to be $9.6 \mathrm{mM}^{-1} \mathrm{~cm}^{-1}$. One unit of GST activity is defined as the amount of enzyme that produce $1 \mu \mathrm{mol} S$-(2,4 dinitrophenyl) glutathione per min.

\section{Statistical analysis}

The statistical analyses were performed by a one-way ANOVA and the Student's $t$-test. The results were expressed as means \pm S.D $(n=10)$. Difference are considered significant when $P<$ 0.05 .

\section{Results and discussion}

Due to Saudi Arabia is facing an acute scarcity of water resources. Some farmers irrigated the date palm (Phoenix dactylifera L.) with sewage water. Therefore, the present study was conducted to compare the effect of irrigation by municipal water (MW) and sewage water (SW) on antioxidant and detoxifying capacities of some commercially Saudi date cultivars, Agwa, Anbr and Safawi in Al-Madinah Al-Munawwarah city. The phenolic contents were determined in examined date cultivars irrigated by MW and SW. The results showed that the phenolic

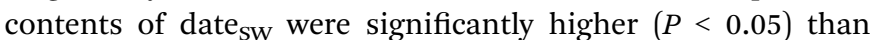

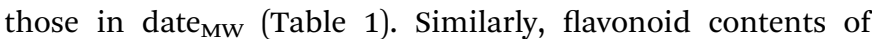
date $_{\text {Sw }}$ were significantly higher $(P<0.05)$ compared with those

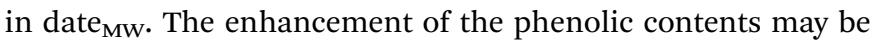
attributed to the accumulation of heavy metals in date fruits. Therefore, the concentration of metals in date fruit was detected. The levels of accumulation of heavy metals, $\mathrm{Cr}, \mathrm{Cu}, \mathrm{Fe}, \mathrm{Mn}$, $\mathrm{Pb}$ and $\mathrm{Zn}$, in date Sw $_{\text {were higher than those of date }}$ (Table
Table 1 The total phenolic and flavonoid contents in tamer fruit of date $_{\mathrm{MW}}$ and date Sw $_{\text {cultivars }}{ }^{a}$

\begin{tabular}{lll}
\hline Cultivar & mg GAE/100 g DW & mg CE/100 g DW \\
\hline Agwah $_{\text {MW }}$ & $308 \pm 6.8^{\mathrm{b}}$ & $42 \pm 0.31^{\mathrm{b}}$ \\
Agwah $_{\text {SW }}$ & $402 \pm 8.8^{\mathrm{a}}$ & $59 \pm 0.29^{\mathrm{a}}$ \\
Anbr $_{\text {MW }}$ & $289 \pm 7.6^{\mathrm{b}}$ & $17 \pm 0.18^{\mathrm{b}}$ \\
Anbr $_{\text {SW }}$ & $314 \pm 5.8^{\mathrm{a}}$ & $34 \pm 0.28^{\mathrm{a}}$ \\
Safawi $_{\text {MW }}$ & $294 \pm 6.6^{\mathrm{b}}$ & $34 \pm 0.32^{\mathrm{b}}$ \\
Safawi $_{\text {SW }}$ & $378 \pm 7.5^{\mathrm{a}}$ & $51 \pm 0.42^{\mathrm{a}}$
\end{tabular}

${ }^{a}$ GAE, gallic acid equivalent, $\mathrm{CE}$, catechin equivalent. Values are presented as means $\pm \mathrm{SD}(n=10)$, values are presented as means \pm SD $(n=10)$. Values with different superscripts (a and b) within each date were significant different $(P<0.05)$.

2). The differences of concentrations are not significant for most of the examined metals except of $\mathrm{Pb}$ and $\mathrm{Cr}$, which had higher significant $(P<0.05)$ in most date ${ }_{\text {sw }}$ compared with date $_{\mathrm{MW}}$. These results indicated that date $\mathrm{SW}_{\mathrm{SW}}$ had a harmful effect on human health. Similarly, lead is known for its toxicity and negative impacts on human health. Absorption of swallowed lead may have a severe danger to public health. Some long lasting negative impacts of lead toxicity includes colic, constipation and anemia (blood related disorder). ${ }^{34}$ In plants, heavy metals such as cadmium (Cd), lead (Pb) and nickel (Ni) are greatly toxic at comparatively low amount. Heavy metal poisonousness is the product of multifaceted interaction of chief noxious ions with other vital or non-essential ions. The metals can be a source of decrease in the hydrolysis products viz., $\alpha$-amylase, phosphatase, RNAs and proteins. They disturb the enzyme activities by substituting metal ions from the metalo-enzymes and prevent various physiological developments of plants. ${ }^{35}$ The induction of phenolic compound biosynthesis was observed in wheat in response to nickel toxicity ${ }^{6}$ and in maize in response to aluminum. ${ }^{12}$ In contrast, the phenolic content was higher in spinach leaves irrigated by fresh water compared with sewage water. ${ }^{36}$

Heavy metals influenced some chemical and physical processes and directly induced reactive oxygen species in living organisms, blocking of some proteins and glutathione. ${ }^{37-39}$ Therefore, the evaluation of antioxidant compounds, antioxidant and detoxifying enzymes was studied. Several methods have been used to evaluate the antioxidant activity of different plants. Usually, these methods measured the ability of antioxidants to scavenge the free radicals. Scavenging the stable DPPH radical model is widely used method to evaluate antioxidant activity. ${ }^{40}$ The phenolic contents for date $\mathrm{MW}_{\mathrm{MW}}$ and date $\mathrm{SW}_{\mathrm{SW}}$ showed a concentration dependent scavenging of DPPH radical (Table 3). The

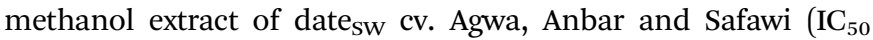
12.44, 11.88 and $12.03 \mu \mathrm{g}$ GAE per $\mathrm{mL}$, respectively) had higher total antioxidant activity compared with date ${ }_{\mathrm{MW}}\left(\mathrm{IC}_{50} 16.8,12.69\right.$ and 14.05, respectively). The correlation coefficient $\left(R^{2}\right)$ between phenolic contents and DPPH scavenging activity ranged from 0.836 to 0.895 indicating the strong correlation for date $\mathrm{MW}_{\mathrm{MW}}$ and date $_{\text {sw. }}$. Similarly, the alcohol and aqueous extracts from organic tomatoes presented higher antioxidant activity in the DPPH test ( 25.43 and $14.28 \%$, respectively) than the conventional tomatoes 


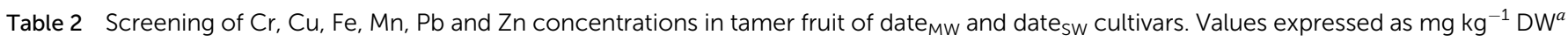

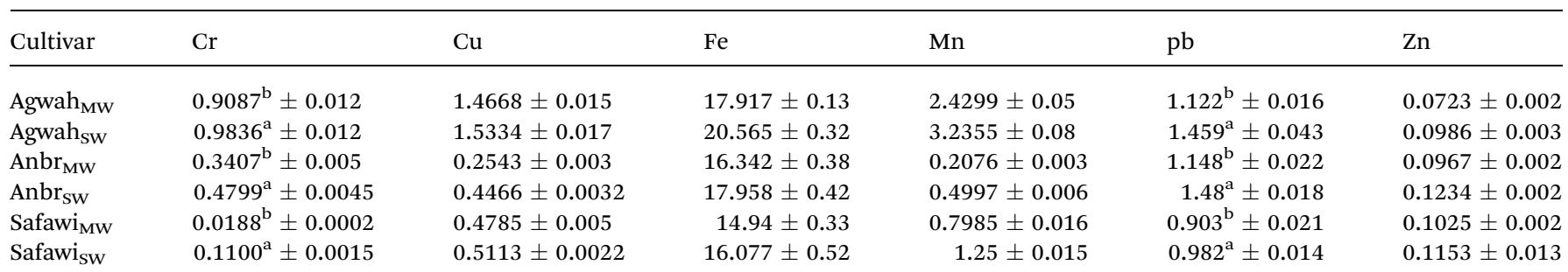

${ }^{a}$ Values are presented as means $\pm \mathrm{SD}(n=10)$. Values with different superscripts (a and b) within each date were significant different $(P<0.05)$.

Table 3 Antioxidant effect of GAE in tamer fruit of date ${ }_{M W}$ and date ${ }_{S W}$ cultivars on reduction of DPPH and $\mathrm{ABTS}$ radical scavenging ${ }^{a}$

\begin{tabular}{|c|c|c|c|c|}
\hline \multirow[b]{2}{*}{ Cultivar } & \multicolumn{2}{|l|}{ DPPH } & \multicolumn{2}{|l|}{ ABTS } \\
\hline & $\mathrm{IC}_{50}(\mu \mathrm{g} \mathrm{GAE})$ & $R^{2}$ & $\mathrm{IC}_{50}(\mu \mathrm{g} \mathrm{GAE})$ & $R^{2 *}$ \\
\hline Agwah $_{\text {Mw }}$ & $16.8 \pm 0.31^{\mathrm{a}}$ & 0.843 & $3.1 \pm 0.08^{\mathrm{a}}$ & 0.948 \\
\hline Agwah $_{\text {SW }}$ & $12.44 \pm 0.21^{\mathrm{b}}$ & 0.844 & $2.24 \pm 0.06^{\mathrm{b}}$ & 0.971 \\
\hline $\mathrm{Anbr}_{\mathrm{MW}}$ & $12.69 \pm 0.38^{\mathrm{a}}$ & 0.895 & $2.0 \pm 0.032^{\mathrm{a}}$ & 0.887 \\
\hline $\mathrm{Anbr}_{\mathrm{SW}}$ & $11.88 \pm 0.18^{\mathrm{b}}$ & 0.847 & $1.79 \pm 0.045^{\mathrm{b}}$ & 0.978 \\
\hline Safawi $_{\text {MW }}$ & $14.05 \pm 0.36^{\mathrm{a}}$ & 0.849 & $2.6 \pm 0.036^{\mathrm{a}}$ & 0.953 \\
\hline Safawi $_{\text {SW }}$ & $12.03 \pm 0.22^{\mathrm{b}}$ & 0.836 & $1.6 \pm 0.022^{\mathrm{b}}$ & 0.939 \\
\hline
\end{tabular}

${ }^{a} \mathrm{GAE}$, gallic acid equivalent. $\mathrm{IC}_{50}$ : is the inhibition concentration as $\mu \mathrm{g}$ GAE of the test sample that decreases $50 \%$ of DPPH and ABTS radicals. Values are presented as means $\pm \mathrm{SD}(n=10)$. Values with different superscripts (a and b) within each date were significant different $(P<$ 0.05). $R^{2 *}$ are the correlation coefficients between phenolic contents and DPPH and ABTS scavenging activity, respectively.

(19.52 and $11.33 \%$, respectively). ${ }^{41}$ On contrast, the spinach leaves irrigated by fresh water had highest antioxidant potential using DPPH assay compared with sewage water. ${ }^{36}$

The ABTS assay is based on the ability of antioxidant to scavenge ABTS radicals. It is a simple and usually used method for the evaluation of antioxidant capacity. ${ }^{42}$ The methanol extracts of date $\mathrm{SW}_{\mathrm{W}} \mathrm{cv}$. Agwa, Anbar and Safawi $\left(\mathrm{IC}_{50} 2.24,1.79\right.$ and $1.6 \mu \mathrm{g}$ GAE per $\mathrm{mL}$, respectively) had higher total antioxidant activity compared with date $\mathrm{MW}_{\mathrm{MW}}\left(\mathrm{IC}_{50} 3.1,2.0\right.$ and 2.6, respectively) (Table 3). The date extract had three-fold free radical scavenging capacity for ABTS radical greater than DPPH radical. The formation of a phosphomolybdenum complex was used as a total antioxidant activity for examined date cultivars. The high absorbance values indicated that the sample possessed significant antioxidant activity. ${ }^{30}$ The phosphomolybdenum complex $\mathrm{EC}_{50}$ value was detected. The methanol extracts of date $\mathrm{Sw}_{\mathrm{Sw}} \mathrm{cv}$. Agwa, Anbar and Safawi (EC50 9.27, 9.54 and $9.16 \mu \mathrm{g}$ GAE per $\mathrm{mL}$, respectively) had higher total antioxidant activity compared with date $\mathrm{MW}_{\mathrm{MW}}\left(\mathrm{EC}_{50} 12.93,12.6\right.$ and 11.44, respectively) (Table 4). The results of the all tested antioxidant assays suggested that new phenolic compounds, with high potential antioxidant capacity, were produced from date ${ }_{\mathrm{SW}}$ compared with date ${ }_{\mathrm{MW}}$.

Peroxidase, an antioxidant enzyme, showed increment in its activity in date $\mathrm{sw}_{\mathrm{sw}} \mathrm{cv}$. Agwa, Anbar and Safawi $(15 \pm 0.25,7 \pm$ 0.12 and $20 \pm 0.34$ units per $\mathrm{g} F \mathrm{FW}$, respectively) compared with date $_{\mathrm{MW}}(9 \pm 0.12,3 \pm 0.05$ and $7 \pm 0.08$ units per $\mathrm{g} F W$,
Table 4 Antioxidant effect of GAE in tamer fruit of date MW $_{\text {and date }}$ an cultivars on formation of phosphomolybdenum complex ${ }^{a}$

\begin{tabular}{lrl}
\hline Cultivar & $\mathrm{EC}_{50}(\mu \mathrm{g} \mathrm{GAE})$ & $\begin{array}{l}\text { Correlation } \\
\text { coefficient }\left(R^{2}\right)\end{array}$ \\
\hline Agwah $_{\text {MW }}$ & $12.93 \pm 0.24^{\mathrm{a}}$ & 0.958 \\
Agwah $_{\text {SW }}$ & $9.27 \pm 0.16^{\mathrm{b}}$ & 0.952 \\
Anbr $_{\mathrm{MW}}$ & $12.6 \pm 0.18^{\mathrm{a}}$ & 0.978 \\
Anbr $_{\text {SW }}$ & $9.54 \pm 0.26^{\mathrm{b}}$ & 0.876 \\
Safawi $_{\text {MW }}$ & $11.44 \pm 0.23^{\mathrm{a}}$ & 0.990 \\
Safawi $_{\text {SW }}$ & $9.16 \pm 0.17^{\mathrm{b}}$ & 0.891
\end{tabular}

${ }^{a} \mathrm{GAE}$, gallic acid equivalent. $\mathrm{EC}_{50}$ : is the efficient concentration as $\mu \mathrm{g}$ GAE of the test sample that increases O.D 0.5 of phosphomolybdenum complex. Values are presented as means \pm SD $(n=10)$. Values with different superscripts (a and b) within each date were significant different $(P<0.05) . R^{2}$ is the correlation coefficient between phenolic contents and formation of phosphomolybdenum complex.

respectively) (Table 5). These enhancements may be attributed to the accumulation of heavy metals (Table 2). Increase in peroxidase activity under heavy metal stress has been reported in palak (Beta vulgaris var Allgreen) grown at sewage water. ${ }^{43}$ The activity of peroxidase was stimulated by the presence of sludge. ${ }^{44}$ Peroxidase also showed increment in its activity in Beta vulgaris $\mathrm{L}$. grown at wastewater irrigated sites as compared to those at ground water irrigated ones. ${ }^{45}$ In industrial wastewater, a significant increase in peroxidase was detected in response to irrigation with wastewater. The magnitude of such increase was directly proportional to the detected amounts of

Table 5 Screening of peroxidase, polyphenoloxidase and glutathione-S-transferase activities in tamer fruit of date $\mathrm{MW}_{\mathrm{MW}}$ and date $\mathrm{SW}_{\mathrm{SW}}$ cultivars $^{a}$

\begin{tabular}{lccc}
\hline Cultivar & $\begin{array}{l}\text { Peroxidase } \\
\text { units per g FW }\end{array}$ & $\begin{array}{l}\text { Polyphenoloxidase } \\
\text { units per g FW }\end{array}$ & $\begin{array}{l}\text { Glutathione-S- } \\
\text { transferase } \\
\text { units per g FW }\end{array}$ \\
\hline Agwah $_{\text {MW }}$ & $9 \pm 0.12^{\mathrm{b}}$ & $61 \pm 0.81^{\mathrm{b}}$ & $2.2 \pm 0.032^{\mathrm{b}}$ \\
Agwah $_{\text {SW }}$ & $15 \pm 0.25^{\mathrm{a}}$ & $123 \pm 2.2^{\mathrm{a}}$ & $2.5 \pm 0.025^{\mathrm{a}}$ \\
Anbr $_{\mathrm{MW}}$ & $3 \pm 0.05^{\mathrm{b}}$ & $10 \pm 0.18^{\mathrm{b}}$ & $1.74 \pm 0.018^{\mathrm{b}}$ \\
Anbr $_{\mathrm{SW}}$ & $7 \pm 0.12^{\mathrm{a}}$ & $33 \pm 0.48^{\mathrm{a}}$ & $3.15 \pm 0.055^{\mathrm{a}}$ \\
Safawi $_{\text {MW }}$ & $7 \pm 0.08^{\mathrm{b}}$ & $52 \pm 1.32^{\mathrm{b}}$ & $3.1 \pm 0.04^{\mathrm{b}}$ \\
Safawi $_{\text {SW }}$ & $20 \pm 0.34^{\mathrm{a}}$ & $88 \pm 2.52^{\mathrm{a}}$ & $3.7 \pm 0.06^{\mathrm{a}}$
\end{tabular}

${ }^{a}$ Values are presented as means $\pm \mathrm{SD}(n=10)$. Values with different superscripts (a and b) within each date were significant different $(P<$ $0.05)$. 
heavy metals in the wastewater ${ }^{46}$ Conversely, peroxidase activity of lettuce decreased along with application of sludge. ${ }^{47}$

The activity of polyphenoloxidase, one of the terminal oxidases in the plant cell, was enhanced under unfavorable conditions. This enzyme, along with peroxidase, is involved in oxidation of phenolic compounds, which function as antioxidants favoring plant cell defense. ${ }^{17}$ Therefore; activation of the enzyme oxidizing phenols could be considered as an indicator of species sensitivity. In the present study, polyphenoloxidase showed enhancement in its activity in date $\mathrm{sw}_{\mathrm{cv}} \mathrm{c}$. Agwa, Anbar and Safawi $(123 \pm 2.2,33 \pm 0.48$ and $88 \pm 2.52$ units per $\mathrm{g} F \mathrm{FW}$, respectively) compared with date $\mathrm{MW}_{\mathrm{MW}}(61 \pm 0.81,10 \pm 0.18$ and $52 \pm 1.32$ units per $g$ FW, respectively) (Table 5). In the unpolluted district, there was no significant difference in polyphenoloxidase activity of the leaves and roots of red clover. At the high concentration of anthropogenic pollutants in the environment (industrial zone) polyphenoloxidase activity in leaves of red clover (sensitive plant to pollution) rose substantially (by 2-3 times in comparison with its roots). ${ }^{48}$

It is often that the activity of glutathione- $S$-transferase is induced by heavy metals. ${ }^{21}$ As such, it was expected that induced glutathione-S-transferase activities would be found in the present study. When glutathione-S-transferase was assayed strongly increasing activity was detected in date sw $_{\mathrm{cv}} \mathrm{cv}$. Agwa, Anbar and Safawi $(2.5 \pm 0.025,3.15 \pm 0.055$ and $3.7 \pm 0.06$ units per $\mathrm{g}$ FW, respectively) compared with date $\mathrm{MW}_{\mathrm{M}}(2.2 \pm 0.032,1.74$ \pm 0.018 and $3.1 \pm 0.04$ units per $\mathrm{g}$ FW, respectively) (Table 5). These enhancements may be attributed to the accumulation of heavy metals (Table 2). Glutathione- $S$-transferases have been associated with the detoxification of xenobiotics and detoxify herbicides in sewage. ${ }^{18,19}$ According to Schröder et al. ${ }^{49}$ there is significant glutathione-S-transferase induction in Picea abies after treatment with $\mathrm{Cd}$ and $\mathrm{Pb}$. When glutathione-S-transferase from Typha latifolia was assayed with the model substrate DCNB, a different pattern of activity was observed, with strongly increasing activities at increasing heavy metal concentrations. ${ }^{50}$

\section{Conclusion}

In the present study, the enhancement of antioxidant and detoxifying capacities, induced by contaminant of sewage, may

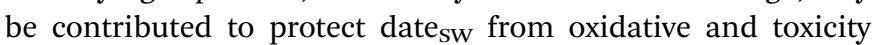
stresses. There are significant differences of the heavy metals in date $_{\mathrm{MW}}$ and date $\mathrm{Sw}_{\mathrm{Sw}}$. Therefore, date $\mathrm{Sw}_{\mathrm{SW}}$ had a harmful effect on human health. Thus, the present study suggests that date palm tree irrigated with sewage water had antioxidant and detoxification mechanisms. However, continued monitoring was suggested to determine long-term effects (i.e., metal accumulation in soil, roots or leaves). Though the metal amounts in wastewater discharges are comparatively low, long-term watering of land with such wastewater can finally cause heavy metal buildup in the soil. Moreover, the repeated application of sewage sludge increases not only the heavy metal content in soil, but also its uptake and accumulation in plant tissues. ${ }^{51}$ Heavy metals accumulated in cultivated soils can be transferred to humans through various exposure pathways causing adverse effects on human health. ${ }^{52}$ If heavy metals enter and accumulate in body tissues faster than the body's detoxification pathways can dispose of, then a gradual build-up of these toxins occurs. High concentration exposure is not a necessity to produce a state of toxicity in the body, as heavy metal accumulation occurs in body tissues gradually and, over time, can reach toxic concentration levels, much beyond the permissible limits. $^{53}$

\section{References}

1 K. Nath, D. Singh, S. Shyam and Y. K. Sharma, J. Environ. Biol., 2009, 30, 227-234.

2 P. C. Nagajyothi, N. Dinakar, S. Suresh, Y. Udaykiran, C. Suresh and T. Damodharam, J. Environ. Biol., 2009, 30, 385-388.

3 D. Dass and R. N. Kaul, Ministry of Environment and Forest, National Wastelands Development Board, New Delhi, India, 1992, p. 33.

4 V. Kanan, R. Ramesh and C. Sasikumar, J. Environ. Biol., 2005, 26, 269-272.

5 S. Kocak, O. Tokusoglu and S. Aycan, Electron. J. Environ., Agric. Food Chem., 2005, 4, 871-878.

6 J. Diáz, A. Bernal, F. Pomar and F. Merino, Plant Sci., 2001, 161, 179-188.

7 P. Wojtaszek, Biochem. J., 1997, 322, 681-692.

8 V. Mittova, M. Volokita, M. Guy and M. Tal, Physiol. Plant., 2000, 110, 42-51.

9 A. Michalak, Pol. J. Environ. Stud., 2006, 15, 523-530.

10 C. Sgherri, E. Cosi and F. Navari-Izzo, Physiol. Plant., 2003, 118, 21-28.

11 Y. Sakihama and H. Yamasaki, Biol. Plant., 2002, 45, 249254.

12 B. Wink El-Shirley, Curr. Opin. Plant Biol., 2002, 5, 218-223.

13 C. H. Jung, V. Maeder, F. Funk, B. Frey, H. Sticher and E. Frosserd, Plant Soil, 2003, 252, 301-312.

14 J. Zhang and M. B. Kirkham, Plant Cell Physiol., 1994, 35, 785-791.

15 K. Radotic, T. Ducic and D. Mutavdzic, Environ. Exp. Bot., 2000, 44, 105-113.

16 O. L. Voskresenskaya, in Polyvariant Development of Organisms, Populations, and Communities, ed. O. L. Voskresenskaya, Mar. Gos. Univ., Yoshkar-Ola, 2006, pp. 77-86.

17 M. M. Rachkovskaya and L. O. Kim, Changes in activities of some oxidases as an index of plant adaptation to industrial pollutants, Gazoustoichivost' rastenii (Plant Tolerance to Gases), ed. V. S. Nikolaevskii, Nauka, Novosibirsk, 1980.

18 H. Gong, Y. Jiao, W.-W. Hu and E.-C. Pua, Plant Mol. Biol., 2005, 57, 53-66.

19 J. P. H. Reade, J. Milner and L. A. H. Cobb, Weed Sci., 2004, 52, 468-474.

20 A. Levine, R. Tenhaken, R. Dixon and C. Lamb, Cell, 1994, 79, 583-593.

21 B. Ezaki, M. Suzuki, H. Motoda, M. Kawamura, S. Nakashima and H. Matsumoto, Plant Physiol., 2004, 134, 1672-1682.

22 M. A. Awad, A. D. Al-Qurashi and S. A. Mohamed, Sci. Hortic., 2011, 129, 688-693. 
23 A. M. R. Elsabea, Ann. Agric. Sci., 2012, 57, 153-159.

24 S. A. Mohamed, M. A. Awad and A. D. Al-Qurashi, Sci. Hortic., 2014, 167, 91-99.

25 F. S. Al-Subaiee, H. M. Al-Ghobari, M. B. Baig, E. A. EI-Hag and M. T. Abu-Riziga, Bulg. J. Agric. Sci., 2013, 19, 1337-1345.

26 Y. S. Velioglu, G. Mazza, L. Gao and B. D. Oomah, J. Agric. Food Chem., 1998, 46, 4113-4117.

27 J. Zhishen, T. Mengcheng and W. Jianming, Food Chem., 1999, 64, 555-559.

28 C. Ao, A. Li, A. A. Elzaawely, T. D. Xuan and S. Tawata, Food Control, 2008, 19, 940-948.

29 R. Re, N. Pellegrini, A. Proteggente, A. Pannala, M. Yang and C. Rice-Evans, Free Radical Biol. Med., 1999, 26, 1231-1237.

30 P. Prieto, M. Pineda and M. Aguilar, Anal. Biochem., 1999, 269, 337-341.

31 M. V. Miranda, H. M. Fernandez Lahor and O. Cascone, Appl. Biochem. Biotechnol., 1995, 53, 147-154.

32 Y. M. Jiang, Z. Q. Zhang, D. C. Joyce and S. Ketsa, Postharvest Biol. Technol., 2002, 26, 241-252.

33 W. H. Habig, M. J. Pabst and B. Jakoby, J. Biol. Chem., 1974, 249, 7130-7139.

34 M. Bolger, C. Carrington, J. C. Larsen and B. Petersen, WHO Food Addit. Ser., 2000, 44, 212-227.

35 S. K. Agarwal, Master Thesis, MDS University, Ajmeer, India, 1999.

36 M. Tehseen, S. Hina and A. Alim-un-Nisa, World Appl. Sci. J., 2014, 32, 1235-1241.

37 A. Hartwing, Antioxid. Redox Signaling, 2001, 3, 625-634.

38 D. Baralkiewicz, M. Kozka, P. Kachlicki, A. Piechalak and A. Tomaszewewska, Int. J. Environ. Anal. Chem., 2008, 88, 979-988.
39 A. Malecka, A. Piechalak and B. Tomaszewska, Acta Physiol. Plant., 2009, 31, 1053-1963.

40 A. Von Gadow, E. Joubert and C. F. Hansmann, Food Chem., 1997, 6, 73-77.

41 R. G. Borguini, D. H. M. Bastos, J. M. Moita-Neto, F. S. Capasso and E. A. F. S. Torres, Braz. Arch. Biol. Technol., 2013, 56, 521-529.

42 Y. Z. Cai, Q. Luo, M. Sun and H. Corke, Life Sci., 2004, 74, 2157-2184.

43 R. P. Singh and M. Agrawal, Chemosphere, 2007, 67, 22292240.

44 M. C. Antolin, I. Muro and M. Snchez-Daz, Environ. Exp. Bot., 2010, 68, 75-82.

45 R. P. Singh and M. Agrawal, J. Environ. Biol., 2010, 31, 727736.

46 H. A. Hashem, R. A. Hassanein, M. H. El-Deep and I. Shouman, Ecotoxicol. Environ. Saf., 2013, 95, 144-152.

47 M. Haghighi, Environ. Sci. Technol., 2011, 5, 165-167.

48 M. G. Polovnikova and O. L. Voskresenskaya, Russ. J. Plant Physiol., 2008, 55, 699-705.

49 P. Schröder, C. Fischer, R. Debus and A. Wenzel, Environ. Sci. Pollut. Res., 2002, 10, 225-234.

50 L. Lyubenova and P. Schröder, Bioresour. Technol., 2011, 102, 996-1004.

51 A. Lakhdar, W. ben Achiba, F. Montemurro, N. Jedidi and Ch. Abdelly, Commun. Soil Sci. Plant Anal., 2009, 40, 35243538.

52 A. Qishlaqi, F. Moore and G. Forghani, Environ. Monit. Assess., 2008, 141, 257-273.

53 K. Sardar, S. Ali, S. Hameed, S. Afzal, S. Fatima, B. Shakoor, S. A. Bharwana and H. M. Tauqeer, Greener J. Environ. Manag. Public Health, 2013, 2, 172-179. 